University of Nebraska - Lincoln

DigitalCommons@University of Nebraska - Lincoln

Faculty Publications from the Harold W. Manter Laboratory of Parasitology

$12-2007$

\title{
Phylogenetic Affinities of Plagiocirrus Van Cleave and Mueller, 1932 with the Description of a New Species from the Pascagoula River, Mississippi
}

\author{
Stephen S. Curran \\ Gulf Coast Research Laboratory, stephen.curran@usm.edu \\ Robin M. Overstreet \\ Gulf Coast Research Laboratory, robin.overstreet@usm.edu \\ Vasyl V. Tkach \\ University of North Dakota
}

Follow this and additional works at: https://digitalcommons.unl.edu/parasitologyfacpubs

Part of the Parasitology Commons

Curran, Stephen S.; Overstreet, Robin M.; and Tkach, Vasyl V., "Phylogenetic Affinities of Plagiocirrus Van Cleave and Mueller, 1932 with the Description of a New Species from the Pascagoula River, Mississippi" (2007). Faculty Publications from the Harold W. Manter Laboratory of Parasitology. 430.

https://digitalcommons.unl.edu/parasitologyfacpubs/430

This Article is brought to you for free and open access by the Parasitology, Harold W. Manter Laboratory of at DigitalCommons@University of Nebraska - Lincoln. It has been accepted for inclusion in Faculty Publications from the Harold W. Manter Laboratory of Parasitology by an authorized administrator of DigitalCommons@University of Nebraska - Lincoln. 


\title{
PHYLOGENETIC AFFINITIES OF PLAGIOCIRRUS VAN CLEAVE AND MUELLER, 1932 WITH THE DESCRIPTION OF A NEW SPECIES FROM THE PASCAGOULA RIVER, MISSISSIPPI
}

\author{
Stephen S. Curran, Robin M. Overstreet, and Vasyl V. Tkach†, \\ Department of Coastal Sciences, The University of Southern Mississippi, 703 East Beach Drive, Ocean Springs, Mississippi 39564. \\ e-mail: stephen.curran@usm.edu
}

\begin{abstract}
Plagiocirrus loboides n. sp. (Digenea: Opecoelidae) is described from Fundulus nottii, F. dispar blairae, F. chrysotus, and Notemigonus crysoleucas from the Pascagoula River in Mississippi. Plagiocirrus loboides differs from P. primus Van Cleave and Mueller, 1932, by having a longer postcecal space (14-25\% of body length vs. about 7\%); a more anterior vitellarium (extending at least to the middle of the ventral sucker vs. to its posterior margin); and larger eggs (51-71 $\mu \mathrm{m}$ long by 23-34 $\mu \mathrm{m}$ wide vs. $40-55 \mu \mathrm{m}$ long by 30-35 $\mu \mathrm{m}$ wide). Plagiocirrus loboides differs from P. testeus Fritts, 1959, by having a long postcecal space (vs. $<5 \%$ of body length); irregular, oblique, contiguous testes (vs. strongly lobed, well separated, tandem testes); and a more extensive vitellarium. Plagiocirrus loboides differs from both congeners by having an ovary comprised of 3 or 4 distinct lobes rather than having an entire ovary. Plagiocirrus wuyienensis Wang, 1981, from Hemimyzon zebroidus in Fujian Province, China, is herein considered a species inquirenda because it has a Y-shaped excretory bladder. Molecular phylogenetic analysis of $28 \mathrm{~S}$ rDNA gene fragments from $P$. loboides and 17 digenean species demonstrates that Plagiocirrus belongs in Opecoelidae.
\end{abstract}

Plagiocirrus Van Cleave and Mueller, 1932, was erected for $P$. primus Van Cleave and Mueller, 1932, a freshwater trematode parasitizing the golden shiner, N. crysoleucas (Mitchill, 1814) (Cypriniformes: Cyprinidae), in Oneida Lake, New York. Van Cleave and Mueller (1932) placed Plagiocirrus in Allocreadiidae, a catchall family for freshwater digeneans of fish at that time. They considered Plagiocirrus similar to Plagioporus Stafford, 1904, also a notional allocreadiid at the time. The initial treatment of Plagiocirrus in Allocreadiidae contributed to a legacy of classification problems in Xiphidiata. Van Cleave and Mueller (1934) advocated a diagnosis of Allocreadiidae based on adult features that was more accommodating than diagnoses followed by most of their contemporary workers. Along with Plagiocirrus and Plagioporus, Van Cleave and Mueller (1934) included Lissorchis Magath, 1917, Macroderoides Pearse, 1924, Triganodistomum Simer, 1929, and Alloglossidium Simer, 1929 in Allocreadiidae, with Alloglossidium accepting species previously placed in Plagiorchis Lühe, 1899 from freshwater fishes in North America. They justified this classification on the basis that: (1) they could find no distinguishing familial characters separating Lissorchis from Allocreadiidae; and (2) members in Macroderoides, Triganodistomum, and Alloglossidium, all previously included in Plagiorchiidae (e.g., Magath, 1917; Pearse, 1924; Simer, 1929), had I-shaped excretory bladders like allocreadiids, whereas, according to Van Cleave and Mueller (1934), true plagiorchiids all had Y-shaped excretory bladders. Van Cleave and Mueller (1934) considered Plagiocirrus, Plagioporus, Lissorchis, and Triganodistomum to be closely related within Allocreadiidae because their members all had sinistral genital pores. Many subsequent workers initiated a greater understanding of the freshwater fish digeneans by emphasizing the importance of larval features when classifying genera. Hopkins $(1933,1934)$ recognized that the North American papillose allocreadiids and at

Received 26 January 2007; revised 20 April 2007; accepted 10 May 2007.

* Department of Biology, University of North Dakota, P.O. Box 9019, Grand Forks, North Dakota 58202-9010.

$\dagger$ Institute of Parasitology, Polish Academy of Sciences, 51/55 Twarda Street, 00-818 Warszawa, Poland. least 1 nonpapillose species, Allocreadium isoporum (Looss, 1894), from Europe, had ophthalmoxiphidiocercariae. DeGiusti (1962) confirmed that A. lobatum Wallin, 1909, from North America, also had an ophthalmoxiphidiocercaria. McMullen (1935) demonstrated that Macroderoides typicus (Winfield, 1929) and Alloglossidium corti (Lamont, 1921) had xiphidiocercariae and transferred the genera back into Plagiorchiidae. Similarly, noting that Lissorchis fairporti Magath, 1917 possessed a xiphidiocercaria, McMullen (1937) considered Lissorchiidae to be a valid family in Plagiorchioidea. Wallace (1939) demonstrated that a tailless cercaria, identified as Cercaria mutabile Cort, 1918, lacking an oral stylet, developed into the adult of Triganodistomum mutabile (Cort, 1918). Wallace (1941) compared the cercaria of $T$. mutabile with that of L. fairporti, which had a tail and oral stylet, and concluded that the overall morphology was otherwise similar and that the 2 species belonged in Lissorchiidae based on similarity of larval and adult features and despite some cercaria differences. Consequently, Triganodistomum and Lissorchis were thereafter segregated from Plagiocirrus and Plagioporus and grouped in Lissorchiidae (Wallace, 1941). Manter (1947) tentatively created Plagioporinae in Opecoelidae for Plagioporus and a number of other notional allocreadiids he recognized belonged in Opecoelidae on the basis that they had cotylomicrocercous cercariae. The larval stages of Plagiocirrus continued to elude collectors and the genus remained in Allocreadiidae.

For a time, Yamaguti (1954) included Plagiocirrus in Zoogonidae presumably because the vitellarium consisted of relatively small, paired groups of follicles. Later, Yamaguti (1958) returned Plagiocirrus to Allocreadiidae placing it in the new subfamily Urorchiinae with Urorchis Ozaki, 1927, a genus with species in Japanese freshwater fishes. Gibson and Bray (1982) advocated a concept of Plagioporinae in Opecoelidae modified from Manter (1947) that included all opecoelids that had a distinct cirrus sac and a canalicular seminal receptacle; however, these authors dealt mainly with European genera and did not classify Plagiocirrus. Shimazu (1990) on the other hand partially followed the classification of Yamaguti (1971) and advocated that Plagiocirrus, Urorchis, and Pseudurorchis Yamaguti, 1971 belonged in Urorchiinae, but placed the subfamily 
within Opecoelidae. Shimazu (1990) considered the key adult features defining Urorchiinae to be a submedian sinistral genital pore, a canalicular seminal receptacle, and preovarian ootype complex. Cribb (2005) did not recognize Urorchiinae as a distinct subfamily because the distinguishing features between Urorchiinae and Plagioporinae were ambiguous; consequently, he considered Plagiocirrus to belong in Plagioporinae, which he tentatively considered a senior subjective synonym for Urorchiinae.

Plagiocirrus primus infects golden shiners over a widespread range in North America from Ontario in the north (see Gibson, 1996), to Florida in the south (Williams and Rogers, 1984; Williams and Dyer, 1992). In addition, the species was reported from the fantail darter Etheostoma flabellare Rafinesque, 1819 (Perciformes: Percidae), in Wisconsin and the large-scaled sucker Catostomus macrocheilus Girard, 1856 (Cypriniformes: Catostomidae), in Idaho (Fischthal, 1947, 1952; Fritts, 1959; Anthony, 1963). Yamaguti (1971) also reported $P$. primus from the common carp Cyprinus carpio carpio Linnaeus, 1758 (as Cyprinus carpio), the northern pike Esox lucius Linnaeus, 1758 (Esociformes: Ecocidae), and E. flabellare (as Catonotus flabellaris lineolatus) from unspecified localities in the United States. Fritts (1959) reported both $P$. primus and a second species $P$. testeus Fritts, 1959 from C. macrocheilus in Idaho. A third species, $P$. wuyienensis Wang, 1981, was described from a river loach Pseudogastromyzon zebroidus (Nichols) (= Hemimyzon zebroidus Nichols, 1925) (Cypriniformes: Balitoridae) from freshwater in Fujian Province, China (Wang, 1981). However, $P$. wuyienensis was described and illustrated with a Y-shaped excretory bladder (Wang, 1981); consequently, we consider it a species inquirenda. In the same publication, Wang (1981) described Stenakron megalobramae Wang, 1981, as a fellodistomid from the Black Amur bream Megalobrama terminalis (Richardson, 1846) (Cypriniformes: Cyprinidae), also from freshwater in Fujian. Cribb (2005) considered S. megalobramae to be a species inquirenda because of its superficial description. We note that $S$. megalobramae conspicuously resembles species in Plagiocirrus and occurs in a cyprinid, but the uterus does not occupy the posttesticular space, and therefore we hesitate to consider it a member of Plagiocirrus.

During April through June of 2003, and again in May of 2005, various fishes from the Pascagoula River were sampled for trematodes. A new species belonging in Plagiocirrus occurred in the intestine of 3 species of topminnows and 1 individual golden shiner. The species is herein described and partial 28S rDNA gene sequences from the species are compared to those of other Xiphidiata to test existing hypotheses regarding the systematic position of Plagiocirrus.

\section{MATERIALS AND METHODS}

Fish were captured from oxbows associated with the Pascagoula River, in the Upper Pascagoula River Wildlife Management Area, George County, Mississippi, with the use of a kick net or 3-m-long seine with 7-mm mesh. Fish were immediately transported live to the Gulf Coast Research Laboratory, in Ocean Springs, Mississippi, where they were

FiguRE 1. Plagiocirrus loboides n. sp. (Digenea: Opecoelidae) from the intestine of Fundulus nottii, ventral view of holotype. Scale bar $=$ $275 \mu \mathrm{m}$.

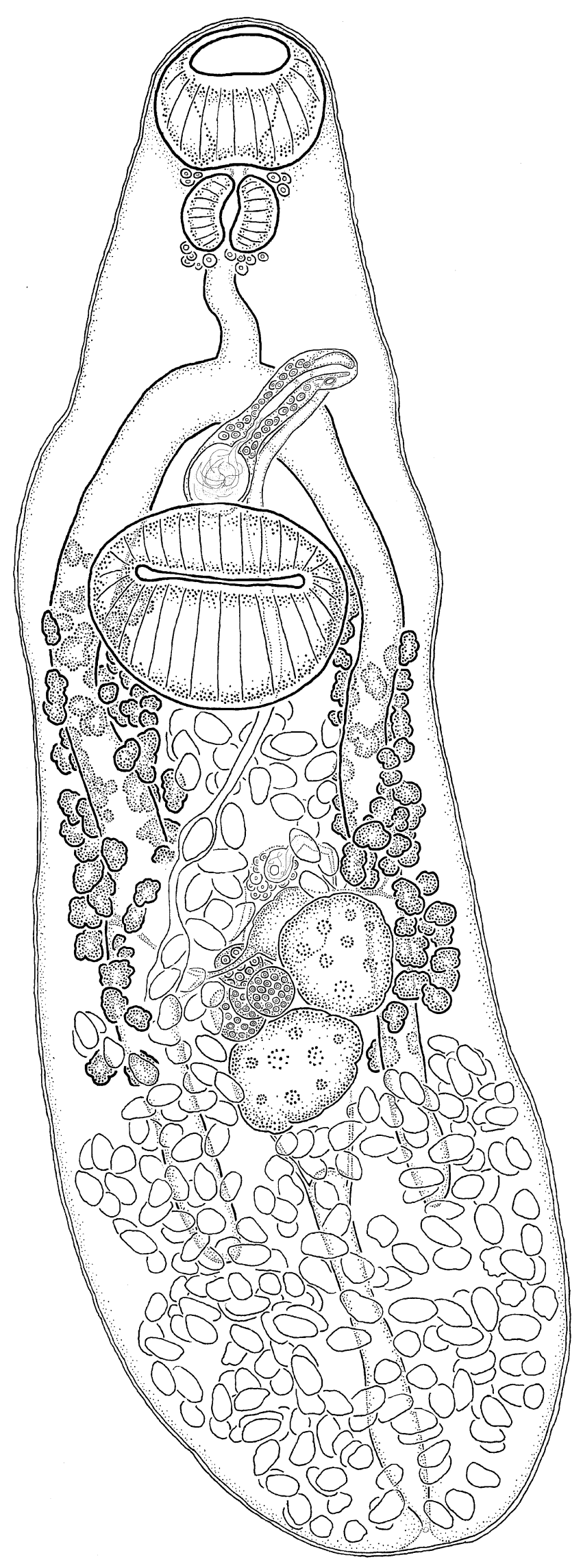




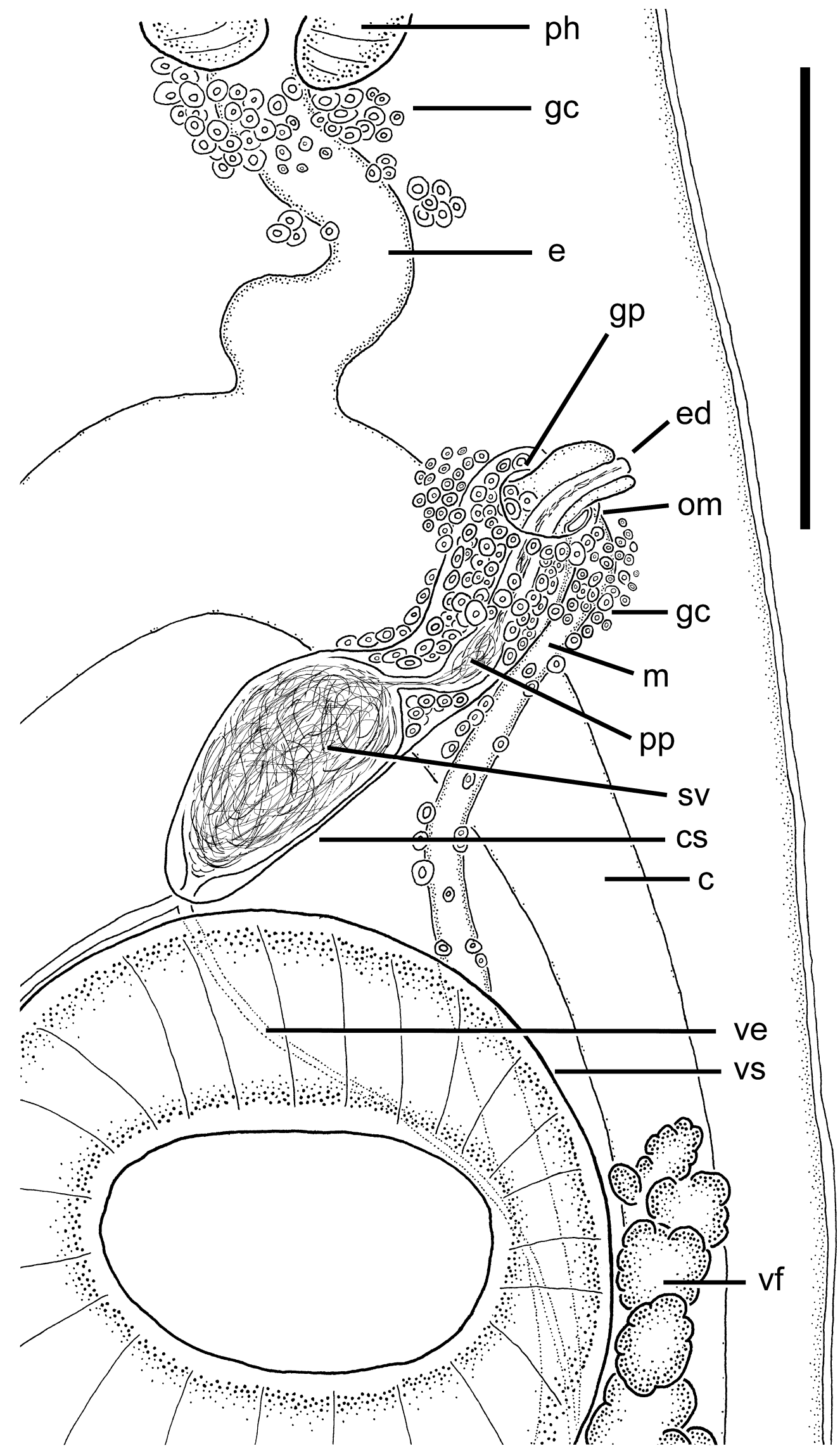


necropsied within 3 days and examined for trematodes. Collected worms were placed briefly in $0.85 \%$ saline solution, then either fixed with near-boiling tap water and placed in 5\% neutral buffered formalin solution or directly into $95 \%$ ethanol. Specimens in formalin were later rinsed in distilled water, stained with aqueous Van Cleave's hematoxylin, and partially dehydrated in a graded ethanol series. Drops of lithium carbonate saturated in $80 \%$ ethanol, plus a small amount of butylamine, were added to make the specimens basic. They were subsequently dehydrated through a graded ethanol series then cleared in clove oil and mounted in Canada balsam on glass slides. Drawings were made with the aid of a drawing tube. Measurements presented in the description are in micrometers and given as the mean followed by the range, when appropriate. Morphological terms used in the description followed those used by Manter (1970). Museum specimens were examined at the United States National Parasite Collection, Beltsville, Maryland (USNPC), and at the Harold W. Manter Laboratory of Parasitology, University of Nebraska, Lincoln, Nebraska (HWML). These included Plagiocirrus primus, holotype (USNPC No. 8565), 3 voucher specimens (HWML 23690); and Plagiocirrus testeus, holotype and 1 paratype (USNPC No. 55622).

Genomic DNA was extracted from 2 ethanol-fixed specimens of the new Plagiocirrus species, under the protocol of Tkach and Pawlowski (1999). A 1,227-bp-long fragment of the nuclear 28S rDNA gene was amplified by PCR from each specimen and sequenced on an ABI Prism $3100^{\text {(i⿱ }}$ automated capillary sequencer following protocols described in Curran et al. (2006). One obtained sequence (GenBank EF523477) was aligned with those of 15 other xiphidiatans: Plagiorchis vespertilionis (Müller, 1784) (AF151931), Brachycoelium salamandrae (Froelich, 1789) (AF151935), Prosthenhystera obesa (Diesing, 1850) (EF032690), A. lobatum (EF032693), Megalogonia ictaluri Surber, 1928 (EF032694), Crepidostomum cornutum (Osborn, 1903) (EF032695), Nagmia floridensis Markell, 1953 (EF032691), Phyllodistomum lacustri (Loewen, 1929) (EF032692), Gorgodera cygnoides (Zeder, 1800) (AF151938), Opecoeloides furcatus (Bremser in Rudolphi, 1819) (AF151937), Macvicaria mormyri (Stossich, 1885) (AF184256), Gaevskajatrema perezi (Mathias, 1926) (AF184255), Peracreadium idoneum (Nicoll, 1909) (AY222209), Saccocoelioides sp. (EF032696), and Hapladena nasonis Yamaguti, 1970 (AY222265). Lissorchis kritskyi Barnhart and Powell, 1979 (EF032689) (Lissorchiidae) and Diplomonorchis leiostomi Hopkins, 1941 (AY222252) (Monorchiidae) were included for outgroup comparison. Sequences were all previously published by Tkach et al. (2001), Olson et al. (2003), or Curran et al. (2006). Sequences were aligned with the use of Clustal $\mathrm{W}$ and further aligned by eye with MacClade ver. 4.03 (Maddison and Maddison, 2000). The full alignment was deposited with European Bioinformatics Institute and is available by anonymous FTP from FTP.EBI.AC.UK in directory/pub/ databases/embl/align and from the EMBLALIGN database through SRS at http://srs.ebi.ac.uk (instructions on retrieval can be found at http:// www3.ebi.ac.uk/Services/webin/help/webin-align/alignSRShelp.html) under accession ALIGN_001133; exclusion sets were added as comments. Regions that could not be aligned unambiguously were excluded from the analysis. Fragments in the alignment were localized at the $5^{\prime}$ end of the nuclear 28S rDNA gene and included the D1-D3 variable domains. Fragments ranged in length from $1,225 \mathrm{bp}$ in $O$. furcatus to $1,253 \mathrm{bp}$ in $H$. nasonis. After gap introduction the alignment measured 1,276 bases long. Of these, 106 ambiguously aligned positions were excluded from the analysis, resulting in a total of 500 variable positions out of 1,170 unambiguous positions. A maximum likelihood (ML) analysis was performed with the use of PAUP* ver. 4.0b10 (Swofford, 2002). Nodal support was calculated based on 1,000 bootstrap replicates with 100 replicates at each step.

\section{DESCRIPTION Plagiocirrus loboides $\mathrm{n}$. sp. \\ (Figs. 1-3)}

Diagnosis (description based on 21 mature specimens): Body elongated, tapering in anterior third, plump, 1,525 (1,319-2,442) long, 539
(393-685) wide. Tegument relatively thin, lacking spines. Eyespot remnants lacking. Oral sucker, 172 (151-206) long, 187 (162-236) wide, with truncated base. Ventral sucker 280 (217-346) long, 307 (257-368) wide. Ratio of oral sucker to ventral sucker width 1:1.4-1.7. Prepharynx, 11-27 long. Pharynx 92 (78-112) long, 114 (89-145) wide. Esophagus slightly longer than pharynx. Forebody 481 (372-730), representing $25-34 \%$ of body length. Intestine bifurcating in forebody, closer to ventral sucker than to oral sucker, with ceca terminating blindly in hindbody. Postcecal space 328 long (201-513), 14-25\% of body length.

Testes oblique, intercecal in mid-hindbody, with irregular outline, contiguous; anterior testis sinistral, 123 (85-161) long, 119 (78-189) wide; posterior testis, 143 (105-173) long, 146 (102-245) wide. Vasa efferencia joining together at proximal end of cirrus sac; cirrus sac claviform, 245 (142-363) long, 59 (45-74) at widest part, containing subspherical to elongated seminal vesicle, prostatic complex and ejaculatory duct; duct entering small genital atrium, everted in some individuals; proximal portion of cirrus sac usually dorsal to ventral sucker, sometimes entirely in forebody. Genital pore opening submedian, sinistral, approximately at level of intestinal bifurcation.

Ovary contiguous with anterior or both testis, comprised of 3 or 4 distinct lobes; overall size 96 (78-156) long, 98 (61-129) wide. Oviduct extending in anterior direction. Ootype and Mehlis' gland located anterior to ovary. Seminal vesicle canalicular. Laurer's canal surrounded by glandular cells at distal end, opening on left side of body on dorsal surface. Uterus looping throughout hindbody; proximal portion usually containing sperm; distal portion a metraterm; metraterm dorsal relative to cirrus sac, joining with dorsal wall of genital atrium. Eggs numerous, operculate, 60 (51-71) long, 27 (23-34) wide measured from metraterm or distal uterus, embryonated, without eye-spotted miracidia. Vitellarium follicular; follicles grouping in 2 lateral bunches surrounding ceca; bunches usually extending from level of middle of ventral sucker to that of middle of posterior testis (near mid-hindbody); anterior extent of vitellarium occurred at anterior margin of ventral sucker in 2 of 21 specimens. Vitelline reservoir medial, ventral relative to other components of female complex.

Excretory vesicle I-shaped, extending to level between posterior testis and cecal terminus, with 2 slender anterolateral secondary collecting ducts extending anteriorly. Pore terminal.

\section{Taxonomic summary}

Type host: Bayou topminnow, F. nottii (Agassiz, 1854) (Cyprinodontiformes: Fundulidae).

Other hosts: Western starhead topminnow, F. dispar blairae Wiley and Jones, 1975; golden topminnow, $F$. chrysotus (Günther, 1866); and golden shiner, Notemigonus crysoleucas (Mitchill, 1814) (Cypriniformes: Cyprinidae).

Site: Intestine.

Type locality: Pascagoula River oxbow, George County, Mississippi $\left(30^{\circ} 52^{\prime} 49.72^{\prime \prime} \mathrm{N}, 88^{\circ} 45^{\prime} 43.47^{\prime \prime} \mathrm{W}\right)$.

Specimens deposited: Holotype (USNPC No. 99674); paratype (USNPC No. 99675); 2 paratypes (HWML 48535, 48536).

Etymology: The Greek adjectival name loboides refers to the lobed condition of the ovary in mature specimens measuring $>1.5 \mathrm{~mm}$ in body length. The specific epithet was given in the form of an adjective to agree with the masculine genus name, which is a mixture of the Greek Plagio (oblique) and Latin cirrus. We presume the genus name was intended to be a noun representing the oblique cirrus.

\section{Remarks}

Cribb (2005), like Manter (1947), considered Plagiocirrus probably closely related to Plagioporus in Opecoelidae rather than Allocreadiidae on the basis of many shared adult features. We agree with this assessment and note that the metraterm occurs dorsal relative to the cirrus sac and enters the dorsal aspect of the genital atrium in species of Plagiocirrus and in members of Opecoelidae, whereas the metraterm enters

$\leftarrow$

FIGURE 2. Terminal genitalia and nearby features, ventral view showing pharynx (ph), gland cells associated with esophagus (gc), esophagus (e), genital pore ( $\mathrm{gp}$ ), ejaculatory duct (ed), opening to metraterm (om), gland cells associated with genital pore ( $\mathrm{gc})$, metraterm (m), pars prostatica (pp), seminal vesicle (sv), cirrus sac (cs), ceca (c), vas efferens (ve), ventral sucker (vs), vitelline follicle (vf). Scale bar $=200 \mu \mathrm{m}$. 


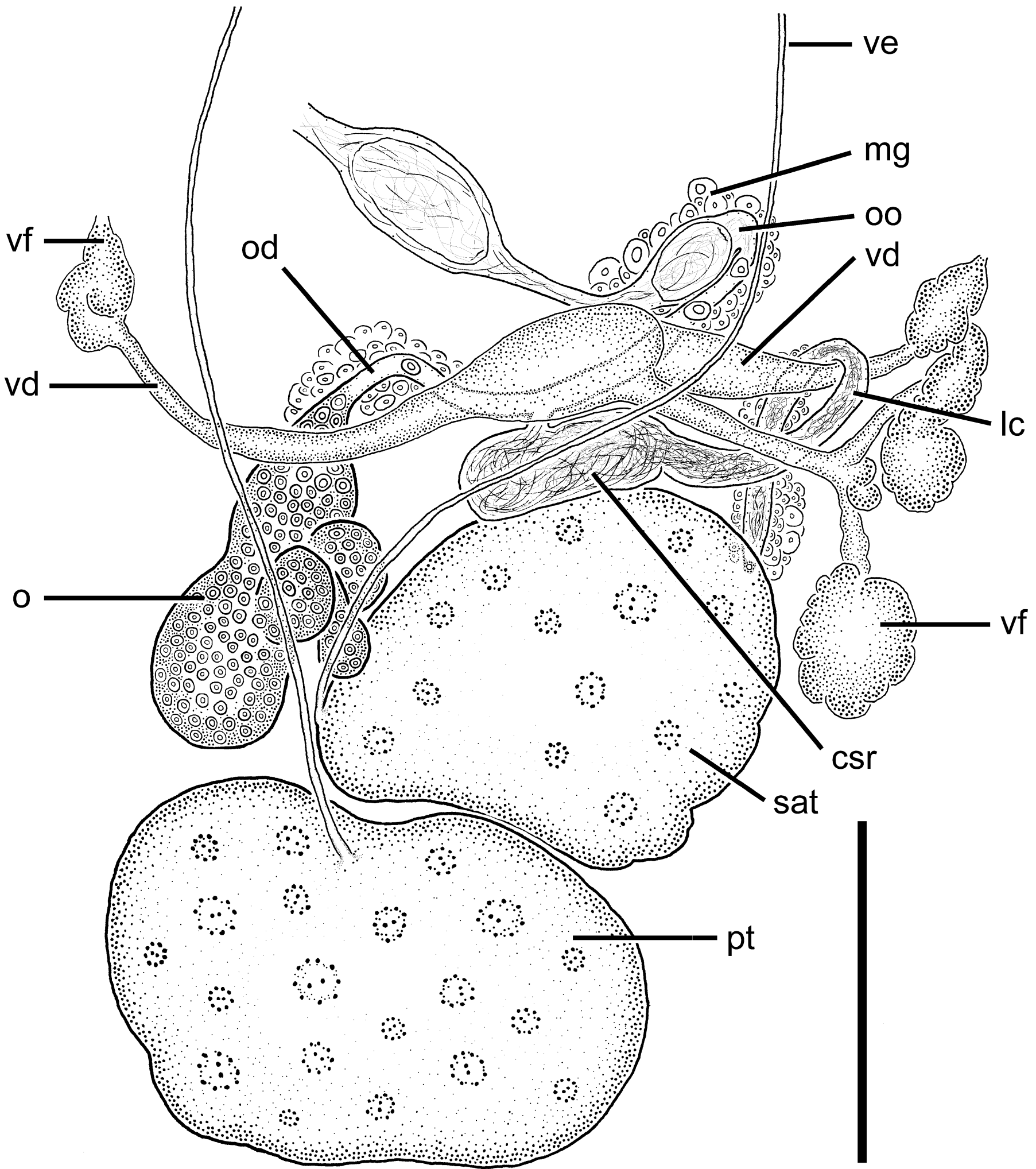

FIGURE 3. Ovarian complex and testes, ventral view showing vas efferens (ve), Mehlis' gland (mg), ootype (oo), vitelline duct (vd), Laurer's canal (lc), vitelline follicle (vf), canalicular seminal receptacle (csr), sinistral anterior testis (sat), posterior testis (pt), ovary (o), ooduct (od). Scale bar $=150 \mu \mathrm{m}$. 


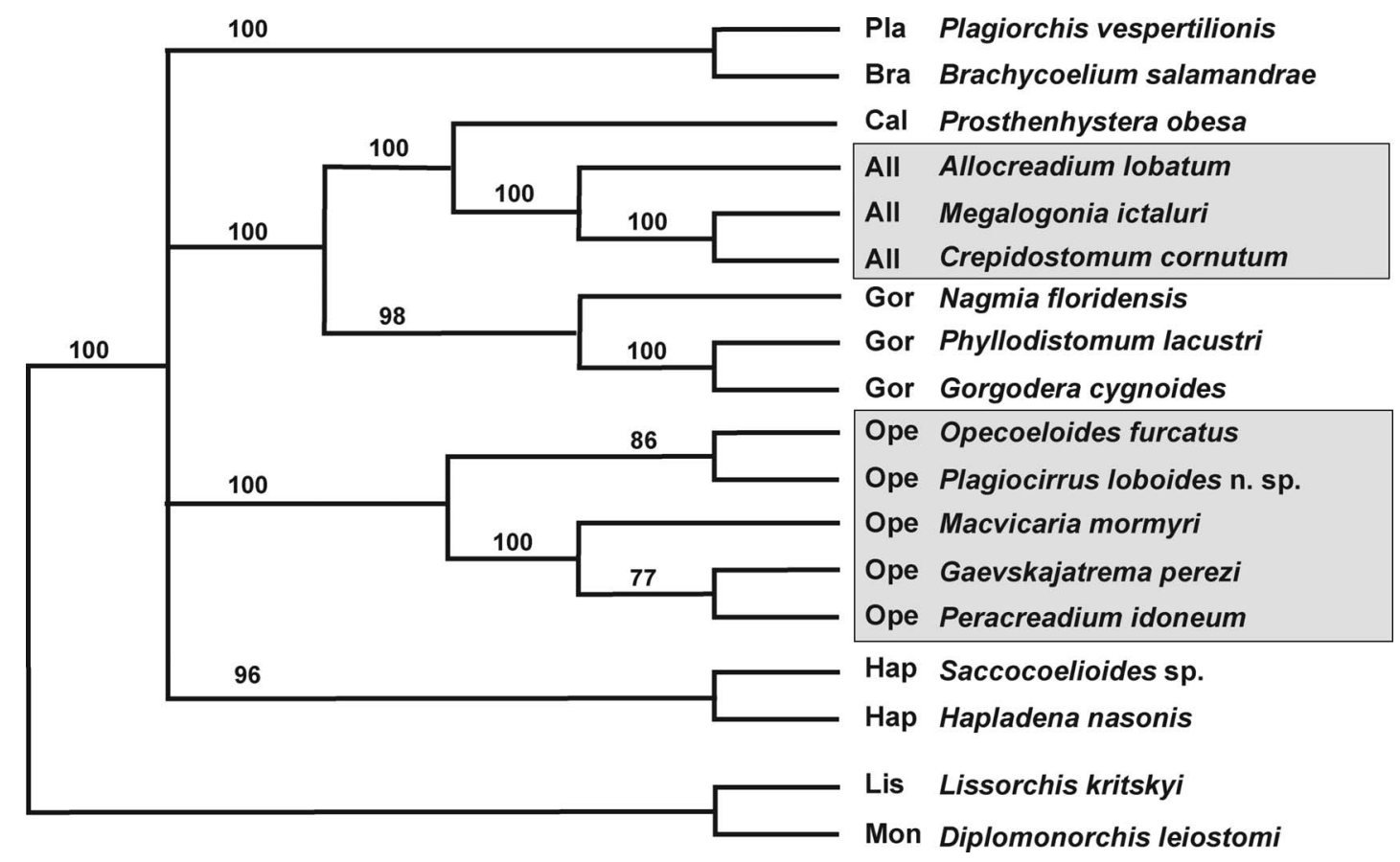

FIGURE 4. Phylogenetic tree based on analysis of partial sequences of $28 \mathrm{~S}$ rDNA gene with the use of the maximum-likelihood algorithm in PAUP*. Bootstrap support values (1,000 bootstraps with 100 replicates at each step) are shown above internodes. Shaded rectangles demonstrate that Plagiocirrus belongs in Opecoelidae and not in Allocreadiidae. Abbreviations: Pla, Plagiorchiidae; Bra, Brachycoeliidae; Cal, Callodistomidae; All, Allocreadiidae; Gor, Gorgoderidae; Ope, Opecoelidae; Hap, Haploporidae; Lis, Lissorchiidae; Mon, Monorchiidae.

the ventral aspect of the genital atrium and occurs ventral relative to the cirrus sac and the cirrus sac overlies the metraterm dorsally in all members of Allocreadiidae. Plagiocirrus may be differentiated from Plagioporus by having a more extensive uterus that occupies almost the entire hindbody rather than one that is restricted to the portion of the hindbody lying anterior to the anterior testis. Plagiocirrus differs further from Plagioporus and from all other plagioporine genera by having a relatively reduced vitellarium that is restricted in lateral bands of follicles confined to the middle and anterior regions of the hindbody. The vitellarium is configured in 2 other ways within the subfamily: (1) vitellarium restricted to lateral bands of follicles that extend from the ventral sucker to the posterior end of the body, and (2) vitellarium consisting of lateral bands that extend in both the forebody and hindbody. Plagiocirrus loboides $\mathrm{n}$. $\mathrm{sp}$. belongs in Plagiocirrus because the vitellarium is confined to lateral bands of follicles that extend from the middle of the posterior testis to at least the middle of the ventral sucker. The vitellarium extends anteriorly to the anterior margin of the ventral sucker in 2 of 21 specimens but the vitellarium never extends into the forebody like in Plagioporus.

Plagiocirrus loboides is most similar to P. primus but differs by having a longer postcecal space measuring $14-25 \%$ of total body length compared with about 7\%, a vitellarium that extends further anteriorly (at least to the middle of the ventral sucker) compared with extending to the posterior margin of the ventral sucker, and slightly longer eggs that measure 51-71 $\mu \mathrm{m}$ long by $23-34 \mu \mathrm{m}$ wide compared with $40-55$ $\mu \mathrm{m}$ long by $30-35 \mu \mathrm{m}$ wide. In addition, the ovary in the new species is situated at the same level as the anterior testis rather than pretesticular. Plagiocirrus loboides differs from the other species in the genus, $P$. testeus, by having a longer post-cecal space, measuring $14-25 \%$ of total body length compared with less than 5\%. Additionally, the testes of $P$. loboides are oblique, contiguous, and irregular whereas they are tandem, well-separated, and lobed in P. testeus. Moreover, the vitellarium is more extensive in $P$. loboides extending anteriorly from the region of the testes to at least the middle of the ventral sucker compared with being confined between the ovarian level and the posterior margin of the ventral sucker. Plagiocirrus loboides is most easily distinguished from its congeners by having an ovary comprised of 3 or 4 lobes rather than an entire one. Seventeen of 21 mature specimens of $P$. loboides measuring $>1.4 \mathrm{~mm}$ in body length possessed a lobed ovary. Only 4 of 21 mature specimens measuring 1.3-1.4 $\mathrm{mm}$ long had a subspherical, entire ovary. Because the ovary is lobed in all specimens measuring more than $1.4 \mathrm{~mm}$ long, we consider this a useful feature for identifying P. loboides.

Neither Van Cleave and Mueller (1932) nor Fritts (1959) illustrated or described a bipartite seminal vesicle for species they described in Plagiocirrus. Mueller (1934) illustrated and described a simple, undivided seminal vesicle in specimens of $P$. primus from Oneida Lake. Yamaguti (1971) considered the presence of a bipartite seminal vesicle to be an important generic level feature for Plagiocirrus. Yamaguti (1971) refigured the holotype of $P$. primus (USNPC No. 8565), including what he termed a bipartite internal seminal vesicle in the drawing. We compared our specimens to the holotype of $P$. primus, 3 voucher specimens of $P$. primus (HWML 23690), as well as the holotype and 1 paratype of $P$. testeus (USNPC No. 55622) and concluded that all the species shared the same condition of having either a subspherical or a slightly elongate seminal vesicle rather than a bipartite one because a muscular sphincter differentiating 2 distinct portions was absent (Fig. 2).

Cribb (2005) considered the presence of a canalicular seminal receptacle an important feature characterizing Plagioporinae, but noted that a canalicular seminal receptacle had never been reported or observed in species of Plagiocirrus. Additionally, Cribb (2005) believed all members of Plagioporinae lacked a uterine seminal receptacle. We observed a canalicular seminal receptacle in P. loboides (Fig. 3) and noted that copious amounts of sperm were also present in the proximal uterus of every live specimen we observed.

\section{Molecular analysis}

Maximum-likelihood analysis of partial 28S rDNA gene sequences including 2 outgroup species (L. kritskyi + D. leiostomi) and an ingroup consisting of $P$. loboides and members of 7 digenean families resulted in a phylogenetic tree showing 4 main clades as a polytomy: (1) Haploporidae; (2) Opecoelidae; (3) Gorgoderidae + Callodistomidae + Allocreadiidae; and (4) Plagiorchiidae + Brachycoeliidae (Fig. 4). The 4 clades and almost all subclades were characterized by very high bootstrap support values (Fig. 4). This analysis unequivocally places Plagiocirrus in the Opecoelidae, thus supporting the original viewpoint by 
Shimazu (1990) that the genus belonged in Opecoelidae. Our analysis did not corroborate the notion advocated by Cribb (2005) that Plagiocirrus belongs in the subfamily Plagioporinae. Plagiocirrus branched most closely with the opecoeline $O$. furcatus rather than with the 3 plagioporine species M. mormyri, G. perezi, and P. idoneum (Fig. 4). Our results suggest that relationships among genera in Plagioporinae as perceived by Cribb (2005) in the most recent review of Opecoelidae might need reevaluation. The idea that Plagiocirrus may belong in Urorchiinae as advocated by Yamaguti (1971), but as a member of Opecoelidae rather than Allocreadiidae as promoted by Shimazu (1990), must be revisited.

\section{ACKNOWLEDGMENTS}

Sarah Abel (Ocean Springs High School, 2003) ably assisted with fieldwork and laboratory procedures. We also are grateful to Mark Peterson (The University of Southern Mississippi) and Gretchen Waggy (Mississippi Department of Marine Resources Grand Bay National Estuarine Research Reserve) for verifying fish identifications. We thank Jeffrey Bell and Kenneth Drees (both from University of North Dakota) for helping to prepare specimens for DNA sequencing. F. Agustíne Jiménez-Ruiz (HWML) and Mrs. Patricia A. Pilitt (USNPC) kindly supplied SSC with bench space and help with examining specimens. Material is based upon work supported by the National Science Foundation under grants 0508856, 0529684, and 0608603 to RMO.

\section{LITERATURE CITED}

Anthony, J. D. 1963. Parasites of eastern Wisconsin fishes. Transactions of the Wisconsin Academy of Sciences, Arts and Letters 52: $83-95$.

CribB, T. H. 2005. Family Opecoelidae Ozaki, 1925. In Keys to the Trematoda, Volume 2, A. Jones, R. A. Bray, and D. I. Gibson (eds.). CAB International and the Natural History Museum, London, U.K., p. 433-531.

Curran, S. S., V. V. Tkach, and R. M. Overstreet. 2006. A review of Polylekithum Arnold, 1934 and its familial affinities using morphological and molecular data, with description of Polylekithum catahoulensis sp. nov. Acta Parasitologica 51: 238-248.

DeGiusti, D. L. 1962. Ecological and life history notes on the trematode Allocreadium lobatum (Wallin, 1909) and its occurrence as a progenetic form in amphipods. Journal of Parasitology 58: 22.

Fischthal, J. H. 1947. Parasites of northwest Wisconsin fishes. I. The 1944 survey. Transactions of the Wisconsin Academy of Sciences, Arts and Letters 37: 157-220.

. 1952. Parasites of northwest Wisconsin fishes. III. The 1946 survey. Transactions of the Wisconsin Academy of Sciences, Arts and Letters 41: 17-58.

FRITTS, D. H. 1959. Helminth parasites of the fishes of northern Idaho. Transactions of the American Microscopical Society 78: 194-202.

GiBson, D. I. 1996. Guide to the parasites of fishes of Canada. Part IV. Trematoda. Canadian Special Publication of Fisheries and Aquatic Sciences 124: 1-373.

- AND R. A. BRAY. 1982. A study and reorganization of Plagioporus Stafford, 1904 (Digenea: Opecoelidae) and related genera, with special reference to forms from European Atlantic waters. Journal of Natural History 16: 529-559.

Hopkins, S. H. 1933. The morphology, life histories and relationships of the papillose Allocreadiidae (Trematodes) (preliminary report) Zoologischer Anzeiger 103: 65-74.

- 1934. The papillose Allocreadiidae. Illinois Biological Monographs 13: $1-80$.

MadDison, D. R., AND W. P. MAdDison. 2000. MacClade4: Analysis of phylogeny and character evolution. Sinauer Associates, Sunderland, Massachusetts.

Magath, T. B. 1917. The morphology and life history of a new trematode parasite, Lissorchis fairporti nov. gen., et nov. spec. from the buffalo fish, Ictiobus. Journal of Parasitology 4: 58-69.
MANTER, H. W. 1947. The digenetic trematodes of marine fishes of Tortugas, Florida. The American Midland Naturalist 38: 257-416.

. 1970. The terminology and occurrence of certain structures of digenetic trematodes, with special reference to the Hemiuroidea. In H. D. Srivastava Commemorative Volume, K. S. Singh and B. K. Tandon (eds.). Indian Veterinary Research Institute, Izatnagar, Uttar Pradesh, India, p. 27-33.

McMullen, D. B. 1935. The life histories and classification of two allocreadiid-like plagiorchiids from fish, Macroderoides typicus (Winfield) and Alloglossidium corti (Lamont). Journal of Parasitology 21: 369-380.

. 1937. A discussion of the taxonomy of the family Plagiorchiidae Lühe, 1901, and related trematodes. Journal of Parasitology 23: $244-258$.

Mueller, J. F. 1934. Parasites of Oneida Lake fishes. Part IV. Additional notes on parasites of Oneida Lake fishes, including descriptions of new species. Roosevelt Wild Life Annals 3: 335-373.

Olson P. D., T. H. CRibB, V. V. TKach, R. A. Bray, and D. T. J. LitTlewood. 2003. Phylogeny and classification of the Digenea (Platyhelminthes: Trematoda). International Journal for Parasitology 33: 733-755.

PeARSE, A. S. 1924. Observations on parasitic worms from Wisconsin fishes. Wisconsin Academy of Sciences, Arts, and Letters 21: 147160.

Shimazu, T. 1990. Trematodes of the genus Urorochis (Digenea: Opecoelidae: Urorchiinae) from freshwater fishes of Japan. Japanese Journal of Parasitology 39: 204-212.

SimER, P. H. 1929. Fish trematodes from the lower Tallahatchie River. The American Midland Naturalist 11: 568-588.

SwOFFord, D. L. 2002. PAUP* version 4.0b10: Phylogenetic analysis using parsimony (and other methods). Sinauer Associates, Sunderland, Massachusetts.

TKaCh, V. V., AND J. Pawlowski. 1999. A new method of DNA extraction from the ethanol-fixed parasitic worms. Acta Parasitologica 44: $147-148$.

, - J. MARIAUX, AND Z. SwIDERSKI. 2001. Molecular phylogeny of the suborder Plagiorchiata and its position in the system of Digenea. In Interrelationships of the Platyhelminthes, D. T. J. Littlewood and R. A. Bray (eds.). Taylor and Francis, London, U.K., p. 186-193.

Van Cleave, H. J., And J. F. Mueller. 1932. Parasites of Oneida Lake fishes. Part I. Descriptions of new genera and new species. Roosevelt Wild Life Annals 3: 9-71.

_ AND - 1934. Parasites of Oneida Lake fishes. Part III. A biological and ecological survey of the worm parasites. Roosevelt Wild Life Annals 3: 161-334.

WallaCe, H. E. 1939. Life history of Triganodistomum mutabile (Cort): Trematoda. Journal of Parasitology 25(6, suppl.): 26-27.

. 1941. Life history and embryology of Triganodistomum mutabile (Cort): (Lissorchiidae, Trematoda). Transactions of the American Microscopical Society 60: 309-326.

WANG, P. 1981. Notes on some trematodes from freshwater fishes in Fujan Province. Journal of the Fujian Normal University 2: 81-90.

Williams, E. H., JR., AND W. G. Dyer. 1992. Some digenea from freshwater fishes of Alabama and Florida including Allocreadium (Neoallocreadium) lucyae sp. n. (Digenea: Allocreadiidae). Journal of the Helminthological Society of Washington 59: 111-116.

-, AND W. A. Rogers. 1984. Pomphorhynchus lucyi sp. n. (Acanthocephala) from fresh and brackish water fishes of the southeastern U.S. Gulf Coast. Journal of Parasitology 70: 580-583.

Yamaguti, S. 1954. Systema helminthum. Part I. Digenetic trematodes of fishes. Satyû Yamaguti (1953), Tokyo, Japan, 405 p.

. 1958. Systema helminthum. Vol. I. The digenetic trematodes of vertebrates. Parts I and II. Interscience, New York, New York, $1,575 \mathrm{p}$

. 1971. Synopsis of digenetic trematodes of vertebrates, Vol. I. Keigaku, Tokyo, Japan, 1,074 p. 